\title{
PENYISIHAN LIMBAH NITROGEN DARI SISTEM AKUAKULTUR MULTITROFIK TERPADU MENGGUNAKAN TANAMAN SAYUR SEBAGAI KONVERTER FOTOAUTOTROF
}

\author{
Sumoharjo*), Asfie Maidie*), Qoriah Saleha*), Erwiantono*), dan \\ Erwin N. Fahlefi**) \\ *) Dosen pada Fakultas Perikanan dan IImu Kelautan, Universitas Mulawarman \\ Jl. Gn. Tabur Kampus Gunung Kelua, Samarinda 75123 \\ **) Mahasiswa pada Fakultas Perikanan dan IImu Kelautan \\ Universitas Mulawarman, Samarinda 75123
}

(Naskah diterima: 28 Januari 2013; Disetujui publikasi: 11 September 2013)

\begin{abstract}
ABSTRAK
Tiga spesies tanaman sayur, kangkung darat (Ipomoea reptana), sawi (Brassica juncea), dan kemangi (Ocimum basilicum) dibandingkan guna mengonversi ammonium dan nitrat nitrogen dari sistem akuakultur. Tanaman tersebut ditanam secara hidroponik menggunakan teknik rakit (rafting technique) dengan tata letak rancangan acak kelompok lengkap (RAKL). Hasil percobaan menunjukkan bahwa tingkat konversi nitrogen oleh ketiga jenis tanaman berbeda secara nyata dengan tingkat retensi nitrogen tertinggi pada tanaman kangkung sebesar $0,73 \pm 0,28 \mathrm{~g}$; diikuti oleh kemangi $(0,30 \pm 0,17 \mathrm{~g})$; dan terakhir oleh sawi $(0,03 \pm 0,07 \mathrm{~g})$. Secara keseluruhan ketiga tanaman mampu menyisihkan limbah nitrogen sebesar $6,70 \%$ dari total produksi TAN dari sisa metabolisme ikan yang dibudidayakan.
\end{abstract}

KATA KUNCl: akuakultur, hidroponik, multitrofik, produksi

ABSTRACT: Removal of nitrogen waste from a multi-trophic aquaculture system using vegetable- plants as photoautotrophic converter. By: Sumoharjo, Asfie Maidie, Qoriah Saleha, Erwiantono, and Erwin N. Fahlefi

Three species of hydroponic-leaf vegetables, spinach (Ipomoea reptana), green mustard (Brassica juncea), and Basil (Ocimum basilicum) were compared for removing ammonium nitrogen and nitrate nitrogen waste from aquaculture tank. The plants were hydroponically planted with rafting technique. Completely randomized block design was used to configure the treatment lay out. The result of the experiment showed that the three plants were significantly different $(P<0.05)$ in removing nitrogen waste with the highest nitrogen retention was $0.73 \pm 0.28 \mathrm{~g} \mathrm{~N}$ achieved by Ipomoea reptana, followed by Ocimum basilicum $(0.30 \pm 0.17 \mathrm{~g} \mathrm{~N})$, and the lowest was by Brassica juncea $(0.03 \pm 0.07 \mathrm{~g} \mathrm{~N})$. In th, the present study has shown that the three plants were able to remove up to $6.70 \% \mathrm{~N}$ of nitrogen waste from fish tank.

KEYWORDS: aquaculture, hydroponic, multi-trophic, integrated, production 


\section{PENDAHULUAN}

Akuakultur adalah sektor produksi pangan yang berkembang cepat dengan rata- rata pertumbuhan 8,9\% tahun; dibandingkan dengan penangkapan $1,2 \%$ dan produksi daging hewan darat yang hanya 2,8\% pada periode yang sama (FAO, 2004). Selanjutnya, FAO (2012) mempublikasikan bahwa produksi akuakultur pada tahun 2010 telah mencapai 59,9 juta ton (belum termasuk tanaman air dan produk bukan makanan) meningkat sebesar $7,5 \%$ dari 55,7 juta ton pada tahun 2009 . Sepertiga dari volume ini diproduksi dari sistem akuakultur yang terpadu dengan pemeliharaan kerang- kerangan dan ikan filter feeder.

Pengembangan sistem akuakultur terpadu telah menarik perhatian dari berbagai kalangan di bidang akuakultur, mulai dari pemerhati, peneliti, hingga praktisi. Hal ini terkait dengan semakin meningkatnya kesadaran tentang dampak limbah akuakultur terhadap lingkungan maupun pengaruhnya terhadap sistem akuakultur itu sendiri yang berakibat pada penurunan daya dukung dalam peningkatan kapasitas produksi. Persoalan ini muncul sebagai akibat dari rendahnya proporsi protein pakan yang dimanfaatkan ikan, di mana hanya sekitar $20 \% 30 \%$ protein pakan yang dikonversi menjadi energi dan untuk pertumbuhan, sisanya dalam bentuk limbah metabolit dilepaskan ke kolom air yang dapat terakumulasi hingga mencapai level yang berbahaya bagi ikan budidaya itu sendiri (Boyd \& Tucker, 1992; Avnimelech \& Ritvo, 2003; Rakocy et al., 2006). Brune et al. (2003) menyatakan bahwa ikan yang mengonsumsi 1 kg pakan dengan rasio konversi pakan (FCR) 3 akan menghasilkan 36\% bahan organik, $75 \%$ $\mathrm{NH}_{3}-\mathrm{N}+10 \%$ urea. Hasil penelitian Colt (1991), menunjukkan bahwa untuk setiap konsumsi 1 kg pakan, ikan membutuhkan $250 \mathrm{~g} \mathrm{O}_{2}$ untuk proses metabolisme dan akan menghasilkan limbah sebesar $340 \mathrm{~g} \mathrm{CO}_{2} ; 30 \mathrm{~g}$ ammonia; 500 $\mathrm{g}$ feses; dan 5,5 g PO - P. Kondisi ini mengakibatkan inefisiensi dalam produksi akuakultur, karena pakan menempati porsi hingga 20\% 40\%dari total ongkos produksi (Losordo $\&$ Westers, 1994).

Untuk mengembalikan nilai pakan yang terbuang tersebut, maka berbagai upaya telah dilakukan. Salah satunya adalah dengan menempatkan tanaman secara hidroponik yang bernilai ekonomis agar limbah dari bak/ kolam ikan yang kaya nutrien tersebut dapat dikonversi menjadi biomassa tanaman yang bisa menjadi nilai tambah dalam produksi, sekaligus sebagai biofilter untuk menghilangkan limbah ammonia, sehingga kondisi air tetap layak bagi sintasan dan pertumbuhan ikan yang dibudidayakan. Perpaduan tanaman hidroponik dengan akuakultur ini dikenal dengan istilah akuaponik.

Pada penelitian ini melibatkan empat jenis organism co-culture selain ikan (cacing Tubifex sp. dan tiga jenis tanaman) dalam sebuah sistem terpadu berbasis rantai makanan yang dikenal dengan nama Integrated MultiTrophic Aquaculture (akuakultur multitrofik terpadu, selanjutnya akan disebut IMTA). Namun demikian, pada artikel ini akan lebih fokus pada bahasan mengenai efisiensi dari tiga jenis tanaman (sawi, kangkung darat, dan kemangi) yang digunakan untuk mengasimilasi limbah amonium nitrogen $\left(\mathrm{NH}_{4}-\mathrm{N}\right)$ dan nitrat nitrogen $\left(\mathrm{NO}_{3}-\mathrm{N}\right)$ yang dihasilkan dari sisa metabolisme ikan.

\section{BAHAN DAN METODE}

\section{Deskripsi Konfigurasi Unit Penelitian}

Sistem IMTA skala pilot yang dibangun tersusun atas dua buah bak ikan, yakni: bak I, volume $1.100 \mathrm{~L}$ dan bak II dengan volume 980 L, aliran air dari bak I ke bak II secara gravitasi yang memanfaatkan perbedaan tinggi muka air 7,25 cm untuk menghasilkan debit air $5 \mathrm{~L} /$ menit. Sebelum masuk ke bak II, air dari bak I terlebih dahulu melewati filter sekunder sepanjang $2 \mathrm{~m}$. Dari bak II, air mengalir menuju wadah biofilter (bioreaktor) yang terbuat dari talang air (water gutter) dan disusun secara seri dalam delapan jalur (8-run-raceways), panjang setiap jalur adalah $2 \mathrm{~m}$, sehingga total panjang wadah filter adalah $16 \mathrm{~m}$. Setiap jalur dihubungkan oleh pipa polyvinil chloride (PVC) diameter 0,75 inci dan juga digunakan untuk menghubungkan bak ikan dengan bioreaktor. Pada outlet filter ditempatkan baskom volume $20 \mathrm{~L}$ sebagai wadah penampungan sementara yang diaerasi kencang (sump). Selanjutnya, air ditarik dengan pompa celup berkekuatan 23 watt untuk dikembalikan ke bak I.

Di dalam bioreaktor, tanaman ditempatkan secara acak berdasarkan jenisnya menggunakan rancangan acak kelompok lengkap (RAKL) mengikuti arah aliran air (dari inlet ke outlet) yang terdiri atas tiga perlakuan dan empat kelompok. Sketsa tata letak percobaan disajikan pada Gambar 1. 


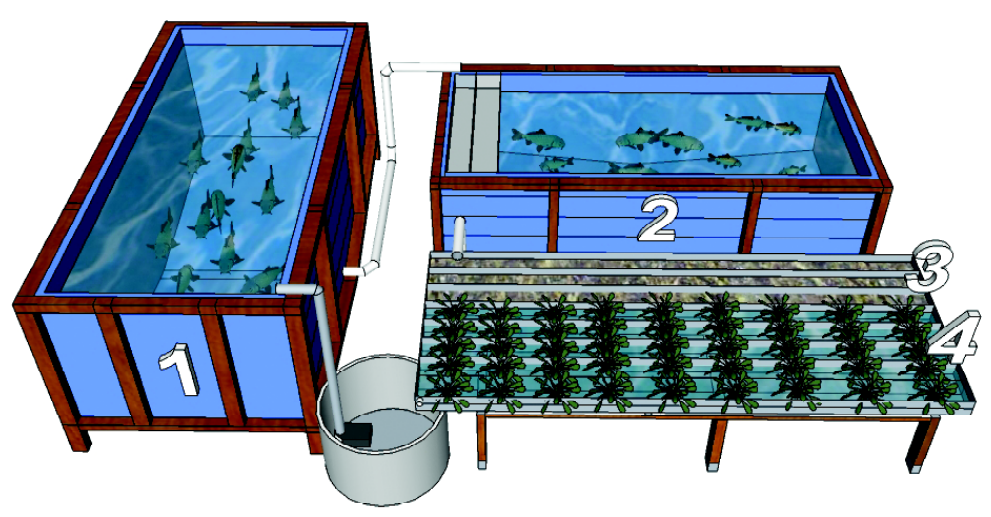

Keterangan (Noted):

Bak ikan nila (1), bak ikan betok (2), jalur cacing sutra (Tubifex sp.) (3), dan jalur hidroponik (kangkung, sawi, dan kemangi) (4) (Tilapia tank (1), climbing perch tank (2), silky worm raceways (3), hydroponic raceways for planting spinach, green mustard, and basil (4))

Gambar 1. Sketsa konfigurasi sistem akuakultur multitrofik terpadu yang diuji

Figure 1. Sketch of tested integrated multi-trophic aquaculture configuration

\section{Pelaksanaan Percobaan}

Pada bak 1 ditebar ikan betok (Anabas testunideus Blk) sebanyak 200 ekor dengan bobot rata- rata $44,4 \pm 9,2$ g sedangkan pada bak 2 ditebar ikan nila (Oreochromis niloticus) sebanyak 220 ekor dengan bobot rata- rata $30,5 \pm 12,64 \mathrm{~g}$. Pemberian pakan protein $32 \%$ dilakukan secara satiasi dengan frekuensi tiga kali sehari untuk masing- masing jenis ikan.

Tiga jenis tanaman (sawi, kangkung, dan kemangi) umur satu minggu, masing- masing sebanyak 40 batang (10 batang per kelompok) ditempatkan secara hidroponik dengan teknik terapung (rafting technique) menggunakan styrofoam. Ukuran rata- rata bobot dan tinggi tanaman yaitu $1,42 \pm 0,16 \mathrm{~g}$ dan $10,85 \pm 1,13 \mathrm{~cm}$ untuk sawi; $2,75 \pm 0,66 \mathrm{~g}$ dan $14,38 \pm 3,12 \mathrm{~cm}$ untuk kangkung; $0,78 \pm 0,08 \mathrm{~g}$ dan $9,88 \pm 1,65$ $\mathrm{cm}$ untuk kemangi. Pengamatan untuk performa tanaman ini dilaksanakan selama 28 hari percobaan.

\section{Pengumpulan Data dan Analisis}

Pengamatan pertumbuhan tanaman dilakukan pada interval waktu tujuh hari sekali. Sedangkan untuk bobot ikan diukur hanya pada awal dan setelah 28 hari percobaan. Pengambilan contoh air untuk mengetahui parameter kualitas air dilakukan setiap tiga hari, meliputi; suhu dan $\mathrm{pH}$ menggunakan $\mathrm{pH}$ meter WTW 330i, oksigen terlarut meng- gunakan DO meter WTW OXI 197i, serta total ammonia nitrogen (TAN), nitrit nitrogen $\left(\mathrm{NO}_{2}-\right.$ $\mathrm{N})$, nitrat nitrogen $\left(\mathrm{NO}_{3}-\mathrm{N}\right)$ menggunakan spektrofotometer GENESYS ${ }^{\mathrm{TM}}$ 10SUV-Visible, dan karbondioksida $\left(\mathrm{CO}_{2}\right)$ diukur dengan metode titrasi $\mathrm{Na}_{2} \mathrm{CO}_{3} 0,045 \mathrm{~N}$ (APHA, 1998).

Analisis tingkat pertumbuhan menggunakan persamaan (Zonnenveld et al., 1991) berikut ini:

Laju pertambahan bobot (growth rate):

$$
G R=\frac{W_{t}-W_{0}}{t}
$$

di mana:

$\mathrm{W}_{0}=$ Bobot awal $(\mathrm{g}) ; \mathrm{W}_{\mathrm{t}}=$ Bobot pada waktu $\mathrm{t}(\mathrm{g})$

Dalam sistem resirkulasi seperti ini, penelusuran total ammonia nitrogen (TAN) dimulai dari produksi TAN sebagai hasil dari proses metabolisme dengan menggunakan persamaan Ebeling et al. (2006):

$$
\mathrm{P}_{\mathrm{TAN}}=\mathrm{F} \times \mathrm{PC} \times 0.092
$$

Di mana:

$\mathrm{P}_{\text {TAN }}=$ Produksi TAN (kgTAN/kg pakan); $\mathrm{F}$ (feed) = Jumlah pakan; PC (protein content) = Kandungan protein (satuan desimal); konstanta 0,092 diperoleh dari asumsi bahwa protein terdiri atas $16 \%$ nitrogen, $80 \%$ nitrogen diasimilasi oleh ikan, $80 \%$ nitrogen yang diasimilasi diekskresikan, dan $90 \%$ nitrogen yang diekskresikan berupa TAN + 10\%urea. 
Dari hasil pengukuran nilai $\mathrm{pH}$, suhu, dan TAN digunakan untuk menghitung proporsi konsentrasi amonium $\left(\mathrm{NH}_{4}{ }^{+}\right)$dan amoniak $\left(\mathrm{NH}_{3}\right)$ dengan menggunakan tetapan disosiasi Wiesman et al. (2007), yakni:

$$
\mathrm{NH}_{3}=\frac{\mathrm{S}_{\mathrm{TAN}}}{1+\mathrm{K}_{\mathrm{D} . \mathrm{NH} 3} \times 10^{-\mathrm{pH}}}
$$

di mana:

$\mathrm{K}_{\mathrm{D} . \mathrm{NH} 3}=\exp \{66,344 /(273+\mathrm{T})\} ; \mathrm{T}={ }^{\circ} \mathrm{C} ; \mathrm{S}_{\mathrm{TAN}}=$ Konsentrasi TAN, sehingga untuk konsentrasi amonium $\left(\mathrm{NH}_{4}^{+}\right)=$TAN $-\mathrm{NH}_{3}$, dan 1 molekul $\mathrm{NH}_{3}=$ $4,2 \mathrm{NO}_{3}$

Tingkat retensi nitrogen oleh tanaman dianalisis setelah 28 hari percobaan. Nilainya ditentukan berdasarkan pada hasil analisis proksimat atas total kjedahl nitrogen tanaman (Takeuchi, 1988), kemudian tingkat retensi nitrogennya dihitung menurut persamaan (Zonnenveld et al., 1991).

$$
\mathrm{RN}_{\text {tanaman }}=\left(\mathrm{W}_{\mathrm{t}} \times \mathrm{N}_{\mathrm{t}}\right)-\left(\mathrm{W}_{\mathrm{o}} \times \mathrm{N}_{\mathrm{o}}\right)
$$

di mana:

$\mathrm{RN}_{\text {tanaman }}=$ Retensi nitrogen oleh tanaman $(\mathrm{g} / \mathrm{kg})$ $\mathrm{N}_{\mathrm{t}}=\mathrm{N}$ dalam tanaman pada waktu $\mathrm{t}$ $\mathrm{N}_{\mathrm{o}}=\mathrm{N}$ semula dalam tanaman

\section{Analisis Statistik}

Data retensi nitrogen dan pertumbuhan tanaman pada masing- masing perlakuan dan kelompok dianalisis keragamannya (ANOVA). Beda rata- rata perlakuan dan kelompok dievaluasi menggunakan uji jarak berganda Duncan dengan tingkat kepercayaan hingga $95 \%(P<0,05)$. Proses analisis secara statistik ini menggunakan perangkat lunak Statistica 8.

\section{HASIL DAN BAHASAN}

\section{Produksi Ikan dan Jumlah Ekskresi Amonia}

Selama 28 hari pemeliharaan, total konsumsi pakan (protein 32\%) oleh kedua jenis ikan adalah 2,464 kg (1,964 kg untuk ikan nila dan $0,5 \mathrm{~kg}$ untuk ikan betok) atau rata- rata konsumsi pakan harian adalah $0,08 \mathrm{~kg} /$ hari dari total konsumsi pakan kedua jenis ikan. Pertumbuhan total ikan nila (Oreochromis niloticus) sebesar $13,11 \pm 15,27 \mathrm{~g}$ sedangkan betok (Anabas testudineus) hanya 5,70 $\pm 5,11 \mathrm{~g}$.

Berdasarkan perhitungan dengan persamaan Ebeling et al. (2006), maka total ammonia nitrogen yang dilepaskan ke air adalah sebesar $2,27 \mathrm{~g} /$ hari. Pada total volume sistem (volume bak ikan + volume wadah filter) 2,21 $\mathrm{m}^{3}$; maka konsentrasi TAN yang terdapat di air $\left(\mathrm{C}_{\text {in }}\right)$ atau konsentrasi TAN sebelum melewati proses biofiltrasi adalah 1,03 gTAN/ $\mathrm{m}^{3} /$ hari.

Konsentrasi TAN ini sangat tipis di bawah konsentrasi TAN yang dianggap beracun, karena pada $\mathrm{pH} 7,5$ dan suhu $28^{\circ} \mathrm{C}$ saja proporsi $\mathrm{NH}_{3}$ dari TAN telah mencapai 0,022 $\mathrm{mg} / \mathrm{L}$ dari $0,025 \mathrm{mg} / \mathrm{L}$ yang merupakan konsentrasi tertinggi yang bisa diterima untuk budidaya komersial (Neori et al., 2004; Chen et al., 2006). Namun demikian, nilai konsentrasi ini tidak bersifat konstan, kecuali pada sistem yang telah mencapai fase steady state $\left(\mathrm{C}_{\text {in }}\right.$ $\mathrm{C}_{\text {out }}=0 \mathrm{mg} / \mathrm{L}$ ).

Fase steady state ini sangat sulit dicapai dalam sistem resikulasi, karena adanya faktor akumulasi sebagai akibat dari tidak seimbangnya laju penyisihan TAN secara asimilatif maupun disimilatif (Wheaton, 1977; Eding et al., 2006; Wiesman et al., 2007) sehingga dikhawatirkan dapat mengakibatkan akumulasi TAN dan mencapai level berbahaya bagi ikan yang dibudidayakan. Hal tersebut terbukti dalam percobaan ini, di mana konsentrasi TAN yang terukur setelah keluar dari bioreaktor ( $C_{\text {out }}$ ) masih mencapai 0,300 $\pm 0,165 \mathrm{mg} / \mathrm{L} /$ hari atau $13,2 \%$ dari produksi TAN $\left(\mathrm{C}_{\text {in }}\right)$ yang kembali ke bak ikan.

\section{Dinamika Nitrogen dalam Sistem}

Amonium sebagai produk akhir dari metabolisme protein diekskresikan oleh ikan. $\mathrm{NH}_{4}^{+}$ (amonium) dan $\mathrm{NH}_{3}$ (amoniak) mengalami kesetimbangan di dalam air, tergantung pada suhu dan pH (Timmons et al., 2001). Jumlah dari kedua bentuk senyawa ini disebut total amonia nitrogen (TAN). Data suhu, pH, TAN, serta proporsi dan $\mathrm{NH}_{3}$ yang terbentuk disajikan dalam Tabel 1.

Berdasarkan pada Tabel 1, menunjukkan bahwa konsentrasi gas amoniak yang terbentuk masih berada pada level yang aman bagi ikan. Nilai tersebut masih jauh di bawah batas toleransi untuk jenis ikan budidaya pada umumnya, yakni sebesar $0,025 \mathrm{mg} / \mathrm{L}$ (Neori et al., 2004; Chen et al., 2006). Untuk lebih jelas, fluktuasi konsentrasi total amonia nitrogen (TAN), $\mathrm{NH}_{3}, \mathrm{NO}_{2}-\mathrm{N}$, dan $\mathrm{NO}_{3}-\mathrm{N}$ yang terbentuk, serta perubahan suhu dan $\mathrm{pH}$ yang terjadi selama percobaan disajikan dalam Gambar 2 
Tabel 1. Nilai rata- rata parameter kualitas air yang terukur di titik inlet dan outlet filter bioreaktor yang diukur

Table 1. The average value of water quality parameters measured in the inlet and outlet of the bioreactor

\begin{tabular}{lccc}
\hline \multicolumn{1}{c}{$\begin{array}{c}\text { Parameter } \\
\text { Parameters }\end{array}$} & $\begin{array}{c}\text { Satuan } \\
\text { Units }\end{array}$ & Inlet & Outlet \\
\hline Suhu (Temperature) & ${ }^{\circ} \mathrm{C}$ & $28.7 \pm 1.2$ & $29.1 \pm 1.3$ \\
$\mathrm{pH}$ & & $7.43 \pm 0.24$ & $7.40 \pm 0.17$ \\
Total amonia nitrogen (TAN) & $\mathrm{mg} / \mathrm{L}$ & $0.288 \pm 0.169$ & $0.300 \pm 0.165$ \\
Ammonium $\left(\mathrm{NH}^{4+}\right)$ & $\mathrm{mg} / \mathrm{L}$ & $0.282 \pm 0.167$ & $0.294 \pm 0.163$ \\
Amoniak $\left(\mathrm{NH}_{3}\right)$ & $\mathrm{mg} / \mathrm{L}$ & $0.0052 \pm 0.0027$ & $0.0054 \pm 0.0026$ \\
Nitrit nitrogen $\left(\mathrm{NO}_{2}-\mathrm{N}\right)$ & $\mathrm{mg} / \mathrm{L}$ & $2.746 \pm 3.160$ & $2.684 \pm 3.026$ \\
Nitrat nitrogen $\left(\mathrm{NO}_{3}-\mathrm{N}\right)$ & $\mathrm{mg} / \mathrm{L}$ & $0.951 \pm 0.246$ & $0.896 \pm 0.228$ \\
\hline
\end{tabular}
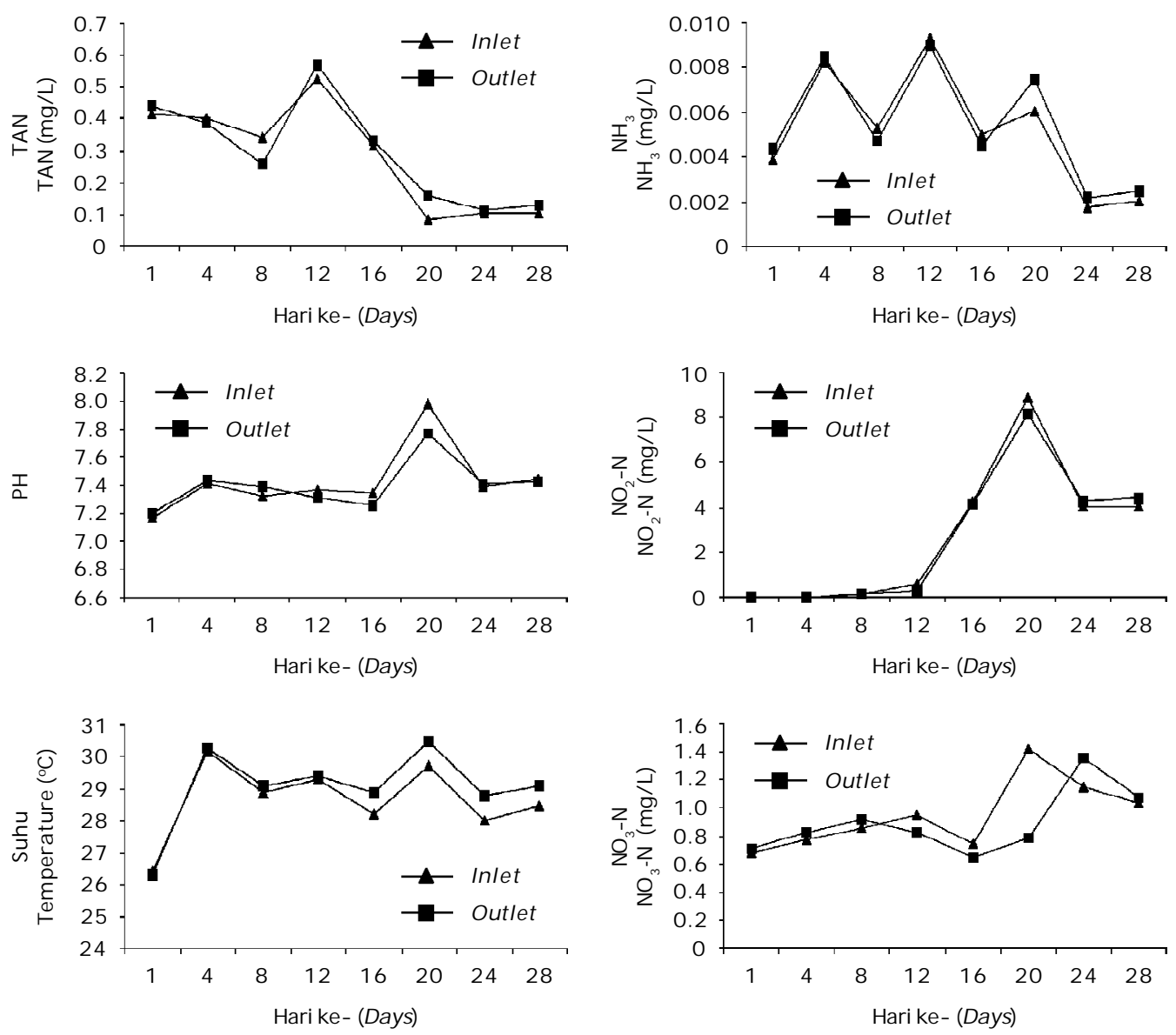

Gambar 2. Fluktuasi konsentrasi TAN, $\mathrm{pH}$, suhu, $\mathrm{NH}_{3}, \mathrm{NO}_{2}-\mathrm{N}$, dan $\mathrm{NO}_{3}-\mathrm{N}$ yang terukur di inlet dan outlet bioreaktor

Figure 2. Fluctuation of TAN, $\mathrm{pH}$, temperature, $\mathrm{NH}_{3}, \mathrm{NO}_{2}-\mathrm{N}$, and $\mathrm{NO}_{3}-\mathrm{N}$ concentration that measured in inlet and outlet of bioreactor 
Terbentuknya nitrat sebagaimana yang terukur dalam sampel air menunjukkan bahwa terdapat proporsi jumlah $\mathrm{NH}_{3}$ yang terdisosiasi karena reaksi nitrifikasi menjadi nitrat $\left(\mathrm{NO}_{3}\right)$, tetapi terjadi akumulasi nitrit $\left(\mathrm{NO}_{2}\right)$ di dalam filter sehingga menghambat pembentukan nitrat. Namun demikian, karena selama percobaan nilai $\mathrm{pH}>7,0$ maka tidak terbentuk asam nitrious $\left(\mathrm{HNO}_{2}\right.$ ) yang berbahaya bagi ikan. Menurut Colt (1991), bahwa asam nitrious akan terbentuk pada $\mathrm{pH}<6,0$. Akumulasi nitrit yang terjadi lebih utama terjadi karena rendahnya proporsi amoniak yang terbentuk sebagai sumber substrat untuk bakteri nitrifier. Chen et al. (2006) menyatakan bahwa laju nitrifikasi berbanding lurus dengan jumlah amoniak sebagai substrat yang bereaksi. Namun demikian, diatom dan alga, misal nya Chlor ella mampu mereduksi nitrat $\left(\mathrm{NO}_{3}^{-}\right)$menjadi nitrit $\left(\mathrm{NO}_{2}^{-}\right)$. Reduksi ini menjadi sumber nitrit kedua dalam perairan. Akumulasi nitrit dalam perairan sangat berbahaya, karena sifat toksisitasnya yang bahkan lebih toksik daripada amoniak (Watten \& Sibrell, 2006).

Konsentrasi ammonium dan nitrat yang terukur di air merupakan sisa nutrien yang belum diasimilasi oleh tanaman yang ditanam secara hidroponik di bioreaktor. Meskipun bakteri heterotrof juga membutuhkan ammonium sebagai sumber nutrien (Madigan et al., 2003), tetapi hanya jumlah nitrogen yang diasimilasi oleh tanaman yang dihitung dalam penelitian ini.

\section{Pertumbuhan Tanaman dan Tingkat Konversi Nitrogen}

Tanaman (sawi, kangkung, dan kemangi) yang ditempatkan secara hidroponik dalam bioreaktor menunjukkan pertumbuhan yang berbeda secara signifikan $(\mathrm{P}<0,05)$.

Kangkung darat (Ipomea reptana) memberikan pertumbuhan yang paling cepat sehingga pada hari ke- 14 sudah dapat dipanen, kemudian tunasnya ditanam kembali (histogram hari ke- 21). Untuk sawi (Brassica juncea) mengalami puncak pertumbuhan hanya sampai pada hari ke- 21 kemudian bobotnya mulai berkurang pada hari ke- 28 sedangkan kemangi (Ocimum basilicum) terus mengalami pertumbuhan dan mulai melampaui bobot sawi pada hari ke- 21 dan sudah siap panen pada hari ke- 28.

Meskipun pada bobot awal ragam ketiga jenis tanaman ini sudah berbeda nyata $(P<0,05)$ namun pertambahan bobotnya mengalami kesamaan pada hari ke- 7, kemudian kembali berbeda nyata pada hari ke- 14 (Gambar 3). Berdasarkan hasil uji lanjut beda nilai tengah dengan uji jarak nyata berganda Duncan (JNBD), terlihat pertambahan bobot kangkung berbeda secara nyata sedangkan antara sawi dan kemangi tidak berbeda nyata. Selanjutnya pertambahan bobot tanaman kembali tidak berbeda dari hari ke- 21 sampai dengan hari ke- 28.

Pertumbuhan tanaman secara kelompok, juga tidak berbeda secara nyata, kecuali pada hari ke- 21 , setelah kangkung dipanen seminggu sebelumnya. Perbedaan ragam kelompok ini disebabkan oleh jumlah kangkung yang dipanen dan tunasnya ditanam kembali, karena dari setiap kelompok ada yang bertunas dan ada yang tidak sedangkan kangkung yang dipanen pada hari ke- 14 hanya yang bertunas, maka terjadi variasi yang besar antara setiap kelompok percobaan.

Konversi nitrogen oleh setiap jenis tanaman berbeda- beda, baik kangkung, sawi, maupun kemangi memiliki perbedaan yang nyata untuk meretensi nitrogen. Hasil analisis proksimat menunjukkan bahwa rata- rata retensi nitrogen tertinggi dicapai oleh tanaman kangkung sebesar $0,73 \pm 0,28 \mathrm{~g}$; diikuti oleh kemangi $(0,30 \pm 0,17 \mathrm{~g})$ dan terakhir oleh sawi $(0,03 \pm 0,07 \mathrm{~g})$. Perbedaan rata- rata selisih persentase total Kjedahl nitrogen (TKN) yang terukur pada masing- masing tanaman seperti pada Gambar 4.

Pada Gambar 4, nampak bahwa pada sawi terjadi penurunan kadar nitrogennya hingga

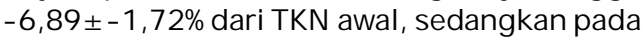
kangkung dan kemangi menunjukkan adanya konversi nitrogen dari air ke dalam biomassa tanaman yang dibuktikan oleh kenaikan TKN hingga $23,80 \pm 5,95 \%$ untuk kangkung dan $14,49 \pm 3,62 \%$ untuk sawi.

Perbedaan yang tajam ini diyakini sebagai pengaruh dari faktor suhu yang cukup panas di Samarinda pada bulan Juni- Juli yang berkisar antara $30^{\circ} \mathrm{C}-35^{\circ} \mathrm{C}$ (Gambar 2), serta keadaan tanaman yang tidak diberi sungkup (dibiarkan terbuka) dan tereskpos cahaya matahari langsung menyebabkan intensitas cahaya matahari yang terlalu kuat. Kondisi tersebut menyebabkan daya serap $\mathrm{N}$ oleh tanaman, terutama sawi terhambat sehingga pertumbuhannya kerdil/ pendek (Gardner et al., 1991). Hal ini juga sejalan dengan hasil pe- 


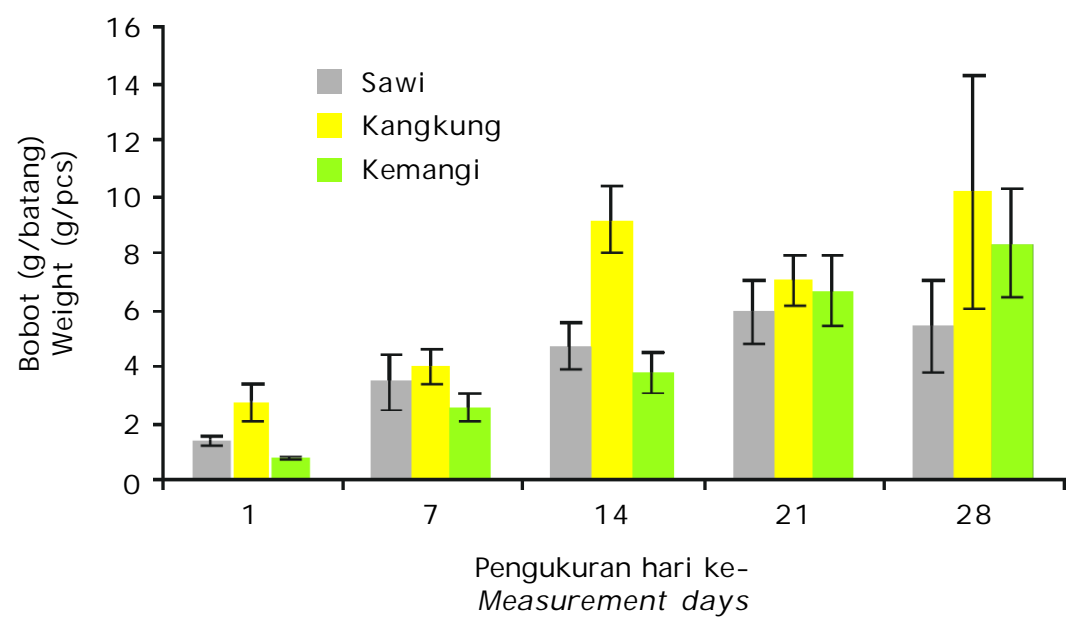

Gambar 3. Laju pertumbuhan masing- masing jenis tanaman dalam biorektor Figure 3. The growth rate of the three plants in the bioreactor

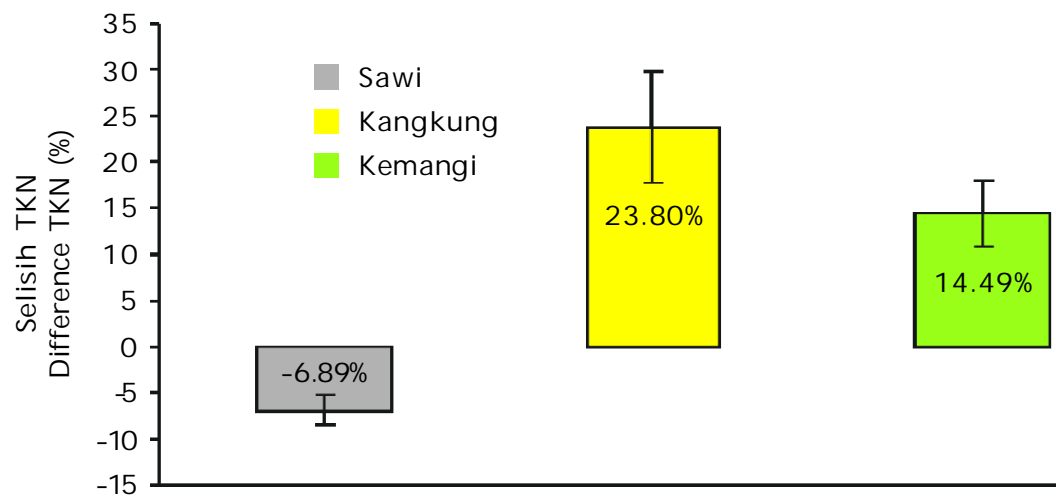

Gambar 4. Rata- rata selisih persentase total Kjedahl nitrogen (TKN) pada setiap tanaman

Figure 4. The average percentage of different total Kjedahl nitrogen of each plant

nelitian Sulistyaningsih et al., (2005) bahwa tanaman sawi yang diberi sungkup plastik lebih baik daripada yang tidak diberi sungkup.

Berdasarkan pada nilai TKN dari ketiga tanaman tersebut, maka dapat dihitung efisiens penyisihan TAN dari bak ikan oleh tanaman, yakni; secara total tanaman telah menyerap $6,70 \%$ TAN dari total produksi amonia ikan dengan rata- rata setiap jenis tanaman adalah; kangkung $(1,14 \pm 0,43 \% N)$; kemangi $(0,47 \pm$ $0,27 \% N)$; dan sawi $(0,05 \pm 0,11 \% N)$. Secara kelompok, peyerapan nitrogen juga berbeda secara nyata, di mana penyerapan tertinggi terjadi pada kelompok 2, yakni $2,5 \% \mathrm{~N}$ dan terendah pada kelompok 4, yakni 1,4\%N dari total produksi TAN ikan.

Meskipun secara total konversi limbah nitrogen ke dalam biomassa tanaman relatif rendah, namun tanaman yang ditempatkan dalam bioreaktor berfungsi dengan baik dalam menyediakan zona rizosfer bagi Rhizobacteria. Selain tanaman, ammonium sisa metabolisme ikan juga digunakan oleh bakteri heterotrof, fitoplankton, dan alga yang tumbuh subur di dalam bioreaktor (Boyd \& Watten, 1989; Boyd \& Tucker, 1992; Madigan et al., 2003), serta mengalami reaksi oksidasi nitrifikasi menjadi nitrit oleh bakteri 
Nitrosomonas sp., kemudian menjadi nitrat oleh bakteri Nitrobacter sp. (Wheton, 1977; Madigan et al., 2003; Watten \& Sibrell, 2006). Dalam bentuk nitrat, nitrogen juga diasimilasi oleh organisme, bukan saja tanaman, tetapi juga fungi, alga, dan bakteri (Waten $\&$ Sibrell, 2006). Selain itu, nitrat akan mengalami denitrifikasi menjadi NO oleh Paracoccus denitrifikans kemudian menjadi $\mathrm{N}_{2}$ oleh Pseudomonas stutzeri secara anaerobik (Madigan et al., 2003).

Berdasarkan pada tingginya dinamika nitrogen dalam bioreaktor tersebut, maka persaingan dalam konversi ammonium dan nitrat pasti terjadi, sehingga menjadi faktor penyebab rendahnya retensi nitrogen ke dalam biomassa tanaman. Di sisi lain, hal tersebut menguntungkan bagi akuakultur, karena konsentrasi amonia cenderung berada pada level yang aman, di mana terhitung secara keseluruhan efisiensi biofiltrasi total amonia nitrogen mencapai 85,0\%TAN selama 28 hari percobaan. Hasil yang dicapai ini lebih tinggi jika dibandingkan dengan hasil penelitian Graber \& Junge (2009) yang menggunakan tanaman terong, tomat, dan mentimun pada sistem akuaponik yang hanya mencapai $69 \%$ penyisihan nitrogen pada keseluruhan sistem.

\section{KESIMPULAN DAN SARAN}

Ketiga jenis tanaman (sawi, kangkung, dan kemangi) memberikan respons yang berbeda secara nyata terhadap penyerapan limbah nitrogen pada sistem akuakultur. Selain fungsinya untuk mengendalikan kualitas air, secara ekonomis tanaman kangkung dan kemangi lebih direkomendasikan untuk digunakan sebagai fitoremediator dalam sistem akuakultur multitrofik terpadu, karena dapat tumbuh dengan baik dan bisa mencapai ukuran komersial, sehingga akan memberikan nilai tambah bagi usaha akuakultur.

\section{UCAPAN TERIMA KASIH}

Terima kasih dan penghargaan disampaikan kepada Prof. Dr. Enang Harris, Dr. Kukuh Nirmala, dan Dr. Munti Yuhana (Ilmu Akuakultur, IPB Bogor) atas semua ide dan saran tentang konsep pengembangan teknologi akuakultur multitrofik terpadu ini, serta Isriansyah, S.Pi., M.Si. dan Heru Kusdianto, S.Pi., M.Si. atas kritik dan saran yang sangat membantu selama penelitian ini. Penelitian ini dibiayai oleh Direktorat Jenderal Penelitian dan Pengabdian
Masyarakat DIKTI melalui skim Hibah Strategis Nasional tahun 2012.

\section{DAFTARACUAN}

American Public Health Association (APHA). 1998. Standard methods for the examination of water and wastewater. Washington D.C.

Avnimelech, Y. \& Ritvo, G. 2003 Shrimp and fish pond soils: processes and management. Aquaculture, 220: 549- 567.

Boyd, C.E. \& Watten, B.J. 1989. Aeration systems in aquaculture. Reviews of Aquatic Science, 1: 425- 472.

Boyd, C.E. \& Tucker, C.S. 1992. Water quality and pond soil analyses for aquaculture. Australia: Auburn University, A.L., 183 pp.

Brune, D.E., Schwartz, G., Eversole, A.G., Collier, J.A., \& Schwedler, T.E.I. 2003. Intensification of pond aquaculture and high rate photosynthetic system. Aquacultural Eng., 28: 65- 86.

Chen, S., Ling, J., \& Blancheton, J.P. 2006. Nitrification kinetics of biofilm as affected by water quality factors. Aquacultural Eng., 34: 179- 197.

Colt, J. 1991. Aquaculture production system. Animal Sci., 69: 4,183- 4,192.

Ebeling, J.M., Timmons, M.B., \&Bisogni, J.J. 2006. Engineering analysis of the stoichiometry of phototrophic, autotrophic, and heterotrophic removal of ammonia- nitrogen in aquaculture system. Aquaculture, 257: 346358.

Eding, E.H. Kamstra, A., Verreth, J.A.K., Huisman, E.A., \& Klapwijk, A. 2006. Design and operation of nitrifying trickling filters in recirculating aquaculture: A Review. J. Aquacultural Engineering, 34: 234- 260.

Food and Agricultural Organization (FAO). 2004. Statement of Fisheries and Aquaculture. Rome. Italy.

Food and Agricultural Organization (FAO). 2012. Statement of Fisheries and Aquaculture. Rome. Italy.

Gardner, F.P., Pearce, R.B., \& Mitchell, R.L. 1991. Physiology of crop plants (Fisiologi Tanaman Budidaya, alih bahasa oleh Susilo, $\mathrm{H}$.). Universitas Indonesia Press. Jakarta, 428 hlm.

Graber, A. \& Junge, R. 2009. Aquaponic system: nutrient recycling from fish wastewater by vegetable production. Desalination, 246: 157- 156. 
Losordo, T.M. \& Westers, H. 1994. System carrying capacity and flow estimation. In Timmons, M.B. \&Losordo, T.M. (Eds.) Aquaculture water systems: engineering design and management. New York. Elsevier, p. 960.

Madigan, M.T., Martinko, J.M., \& Parker, J. 2003. Brock biology of microorganisms. $10^{\text {th }}$ Edition. Southern Illinois University Carbondale. Pearson Education, Inc. USA.

Neori, A., Chopin, T., Troel, M., Buschmann, A.H., Kraemer, G.P., Halling, C., Shpigel, M., \& Yarish, C. 2004. Integrated aquaculture: rationale, evolution, and state of the art emphasizing seaweed biofiltration in modern mariculture. Aquaculture, 231: 361- 391

Rakocy, J.E., Masser, M.P., \& Losordo, T.M. 2006. Recirculating aquaculture tank production systems: aquaponics- integrating fish and plant culture. Revision. SRAC Publication No. 454. Virginia. US.

Sulistyaningsih, E., Kurniasih, B., \& Kurniasih, E. 2005. Pertumbuhan dan hasil caisin pada berbagai warna sungkup plastik. J. IImu Pertanian, 12(1): 65-76.
Takeuchi, Y. 1988. Labrotary work- chemical evaluation of dietary nutriens. In Watanebe (Ed.) Fish Nutrition and marineculture. Kanagawa International Fisheries Training. Japan. Japan International Cooperation Agency (IICA). p. 179- 233.

Timmons, M.B., Ebeling, J.M., Wheaton, F.W., Summerfelt, S.T., \& Vinci, B.J. 2001. Recirculating aquaculture systems. $2^{\text {nd }}$ Edition NRAC Publication, Vol. 01-002. $2^{\text {nd }}$ Edition, Cayuga Aqua Ventures, Ithaca, New York, 650 pp.

Watten, B.J. \& Sibrell, P.L. 2006. Comparative performance of fixed-film biological filter: application of reactor theory. Aquacultural Eng., 34: 198- 213.

Wheaton, F.W. 1977. Aquacultural engineering. Maryland. US: A Wiley-Interscience Publication.

Wiesman, U., Choi, I.S., \&Dombrowski, M. 2007. Fundamental of biological wastewater treatment. WLEY- VCH Verlag $\mathrm{GmbH} \& \mathrm{Co}$. KgaA, Weinheim. Germany.

Zonnenveld, A., Huisman, E.A., \& Boon, J.H. 1991. Prinsip- prinsip budidaya ikan. PT Gramedia Pustaka Utama. Jakarta, 